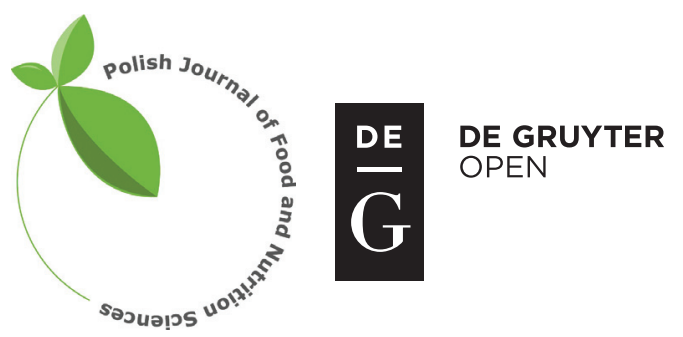

Pol. J. Food Nutr. Sci., 2017, Vol. 67, No. 4, pp. 251-263

DOI: $10.1515 /$ pjfns-2017-0017 http://journal.pan.olsztyn.pl

Review article

Section: Food Quality and Functionality

\title{
Microalgae, a Potential Natural Functional Food Source - a Review
}

\author{
Angélica Villarruel-López ${ }^{1}$, Felipe Ascencio ${ }^{2}$, Karla Nuño ${ }^{3 *}$ \\ ${ }^{1}$ Laboratorio de Microbiología Sanitaria, Centro Universitario de Ciencias Exactas e Ingenierías, \\ Universidad de Guadalajara, Marcelino García Barragán No. 1421, Guadalajara, Jalisco 44430, México \\ ${ }^{2}$ Unidad de Patología Marina, Centro de Investigaciones Biológicas del Noroeste, Instituto Politécnico Nacional 195, \\ Col. Playa Palo de Santa Rita Sur, La Paz, B.C.S. 23096, México \\ ${ }^{3}$ División de Ciencias de la Salud, Centro Universitario de Tonalá, \\ Universidad de Guadalajara, Av. Periférico Norte No. 555, Tonalá, Jalisco 48525, México
}

Key words: microalgae, polysaccharides, fatty acids, pigments, vitamins

Microalgae are a group of microorganisms used in aquaculture. The number of studies regarding their use as a functional food has recently increased due to their nutritional and bioactive compounds such as polysaccharides, fatty acids, bioactive peptides, and pigments. Specific microalgal glucans (polysaccharides) can activate the immune system or exert antioxidant and hypocholesterolemic effects. The importance of algal lipids is based on their polyunsaturated fatty acids, their anti-inflammatory effects, their modulation of lipid pathways, and their neuroprotective action. Microalgae peptides can bind or inhibit specific receptors in cardiovascular diseases and cancer, while carotenoids can act as potent antioxidants. The beneficial biological activity will depend on the specific microalga and its chemical constituents. Therefore, knowledge of the composition of microalgae would aid in identifying, selecting, and studying their functional effects.

\section{INTRODUCTION}

Algae are a large and diverse group of organisms growing in aquatic environments that are able to photosynthetically convert $\mathrm{CO}_{2}$ and minerals to biomass, although some species do grow heterotrophically. The two main forms are macroalgae and microalgae with the latter differentiated by their pigments, reserve substances, cell wall, cellular division characteristics, and morphology.

Macroalgae, or seaweeds, are fast-growing, multicellular, macroscopic nonvascular plants that contain chlorophyll, with sizes reaching up to $60 \mathrm{~m}$ in length. They are classified in groups based on their pigmentation: Chlorophyceae (green algae), Phaeophyceae (brown algae), and Rhodophyceae (red algae). Seaweeds have been used by humans for about 14,000 years and as food products by the Japanese and Chinese cultures for centuries; the Aztec population also collected and cultivated seaweeds [Dillehay et al., 2008; Mc Hugh, 2003; Pulz \& Gross, 2004]. Their applications in the food industry have been increasing, as well as in the textile, pharmaceutical, cosmetic, and biotechnology industries [Bartsh et al., 2008]. Seaweed biomass is used for the production of phycocolloids such as agar-agar, alginates, and carrageenan. Because of their commercial potential,

\footnotetext{
* Corresponding Author: Tel.: +52 (33)35403020, Ext: 64037;

E-mail: karlajanette.nuno@cutonala.udg.mx
}

more than 200 species are utilized worldwide, but the most cultivated and used are the brown algae Laminaria japonica and Undaria pinnatifida; the red algae Porphyra, Eucheuma, Kappapycus, and Gracilaria; and the green algae Monosotroma and Enteromorpha [Lüning \& Pang, 2003].

The microalgae consist of a wide range of autotrophic organisms that grow through photosynthesis in the same way as do plants, and their classification is in constant revision due to new genetic evidence. Nevertheless, they can be classified into two major groups: prokaryotic and eukaryotic [Harun et al., 2010]. The prokaryotic microalgae are the Cyanobacteria (blue-green algae), the taxonomy of which includes five orders: Chroococcales, Oscillatoriales, Nostocales, Stigonematales, and Pleurocapsales. The Prochlorophyta, or freeliving chloroplasts, are another collection of cyanobacteria that represent an artificial group based on their different pigmentation, which is derived from an absence of phycobiliproteins, and in most cases, the presence of chlorophylls $a$ and $b$. One of the main characteristics of cyanobacteria is their fast uptake and storage of nutrients and compounds such as phosphate, cyanophycin (a polymer of aspartic acid and arginine), and a branched $\alpha-1,4$ polyglucan. Some of these microorganisms can produce neurotoxins and hepatotoxins, while others produce therapeutic compounds (e.g., antivirals, inmmunomodulators, inhibitors). The most important Cyanobacteria used in biotechnology are Spirulina (Arhrospira) platensis, Nostoc commune, and Aphanizomenon flos-aquae 
TABLE 1. Main classes and species of microalgae.

\begin{tabular}{lc}
\hline Class & Species \\
\hline & Chaetoceros calcitrans \\
& Chaetoceros gracilis \\
Bacillariophyceae & Nitzchia closterium \\
& Phaeodactylum tricornutum \\
& Thalassiosira pseudonana \\
& Cylindrogheca fusiformis \\
& Dunaliella tertiolecta \\
Chlorophyceae & Tetraselmis suecica \\
& Chlorella vulgaris \\
Eutomatophyceae & Dunaliella salina \\
& Nannochloropsis oculata \\
Prymnesiophyceae & Isochrysis galbana \\
Crysophyceae & Pavlova lutheri \\
& Pavlova salina \\
Cyanophyceae & Cryptomonas rufescens \\
& Nostoc commune \\
Euglenophyceae & Spirulina platensis \\
\hline
\end{tabular}

[Pulz \& Gross, 2004; Gantar \& Svircev, 2010; Duong et al., 2012] (Table 1).

The eukaryotic microalgae include several divisions: Chlorophyta (green algae) is the largest group, and most are unicellular or filamentous freshwater forms; Euglenophyta, which are flagellated unicells that emerged from a secondary endosymbiosis between algae and a protozoan-like host; Rhodophyta, or red algae, resulting from their phycoerythrin content; Cryptophyta, in which most species are photosynthetically active motile unicells; Dinophyta or Dinoflagellata, which represent a wide group, though some species are not used due to their production of harmful toxins; Prymnesiophyta, also called Haptophyta; Glaucophyta, freshwater algae that possess an almost intact cyanelle as their photosynthetic organelle; Chlorarachniophyta, amoeboid/flagellated eukaryotes; and Heterokontophyta, composed of the brown algae Phaeophyta, the yellow-green algae Eustimatophyta (or Xanthophyta), the golden algae Chrysophyta, and the Bacillariophyta (or Diatoms) [Duong et al., 2012; Barsanti et al., 2008; Leblond et al., 2010; McFadden et al., 1997].

Microalgae are cultivated in aquaculture, and in recent years, the number of studies regarding their use as functional foods has increased. This is due to such nutritional characteristics as their cell wall polysaccharide composition, the types and amount of lipids, the conformation of different amino acids, and the presence of pigments and micronutrients. A few microalgae have been identified for commercial application based on these characteristics: Spirulina, Chlorella, Haematococcus, Dunaliella, Botryococcus, and Phaeodactylum. However, other microalgae can also be used [Raja et al., 2008; Wikfors \& Ohno, 2001].

The study of microalgae is less developed than that of seaweeds, but their advantages of faster growth, higher photosynthetic efficiency, and indoor production provide an opportunity for research into new nutritional products and their applications in the food and health industries [Dragone et al.,
2011]. In addition, the biodiversity of microalgae would allow for increasing the number of different sources of bioactive compounds such as carbohydrates, lipids, proteins, and pigments (Table 2) [Markou \& Nerantzis, 2013].

\section{PROTEINS}

The total protein content of the biomass depends on the microbial species; however, during rapid steady-state growth, the protein content can range from 30\% to 55\% of the dry weight. The microalgal cell wall is often disrupted to make the protein, amino acids, and other constituents accessible, or alternatively, enzymatic protein hydrolysis can be used to obtain bioactive peptides [González-López et al., 2010; Kim \& Wijesekara, 2010]. It has been reported that some microalgae contain soluble proteins in their cytoplasm. In addition, microalgae with chloroplasts contain soluble protein, a central pyrenoid, and phycobiliproteins, although some microalgae such as A. plantesis instead have thylakoid bundles circling the peripheral part of the cytoplasm associated with phycobilisomes [Safi et al., 2014].

According to Becker [2007], the general protein composition of the cyanobacteria Spirulina platensis is 43-63\% (dw) with an amino acid profile of leucine, valine, isoleucine, phenylalanine, tyrosine, methionine, cysteine, and tyrosine. Because of its high protein content, it is also considered a food supplement [Templeton \& Laurens, 2015]. The Rhodophyta Porphyridium cruentum contains 28-39\% of protein dry matter with amino acids such as aspartic acid, threonine, serine, glutamic acid, glycine, alanine, cysteine, and valine, among others [Becker, 2007; Safi et al., 2014; Hempler \& Maier, 2012].

In Heterokontophyta, the diatom Phaeodactylum tricornutum ranged from $45-54 \%$ algal dry weight, with $10.3 \%$ phenylalanine as the principal amino acid. In contrast, the predominant amino acids in six species of Bacillariophyta were serine, alanine, arginine, leucine, glycine, aspartate, and threonine. The Eustomatophyta Nannochloropsis sp. has a similar amino acid profile as that of Chlorella vulgaris, with a $30 \%$ protein content of algal dry weight [Chuecas \& Riley, 1969; Gatenby et al., 2003]. When Prymnesiophyta Isochrysis aff. galbana (clone T-Iso) was exposed to low and high levels of nitrate, it showed protein contents ranging between $6.3 \%$ and $19.8 \%$ (dw), and its amino acid composition did not vary with different irradiances during growth. Glutamate and aspartate were present in the same proportions $(9.0-13.5 \%$ of total amino acids), while histidine, methionine, tryptophan, cysteine, and hydroxyl-proline were minor constituents $(0.0-2.6 \%)$ [Brown \& Jeffrey, 1992; Dörner et al., 2014].

The Chlorophyta Tetraselmis sp. has about $64 \%$ soluble protein (dw) after complete disruption of the cell wall, with a predominant amino acid profile of leucine, asparagine, glutamine, glycine, proline, lysine, valine, and serine [Schwenzfeier et al., 2011]. Moreover, the amino acid content in Chlorella sp. is approximately $18 \%$ (dw). In Chlorella vulgaris, whose amino acids were identified, which included $44.7 \%$ (of total amino acids) of the essential amino acids such as cysteine $(0.22 \%)$ and arginine (4.5\%). Eustomatophyta Nannochloropsis sp. has a 30\% (dw) protein content with a similar 
TABLE 2. Common bioactive components found in different microalgal class.

\begin{tabular}{|c|c|c|c|c|}
\hline & Carbohydrates & Lipids & Amino Acids & Pigments \\
\hline Cyanobacteria & $\alpha$-1,4-linked glucan & $16: 0,18: 2,20: 5$ & leucine, valine, phenylalanine & $\begin{array}{l}\beta \text {-carotene, zeaxanthin, } \\
\text { chlorophyll } a\end{array}$ \\
\hline Rhodophyta & Sulfated polysaccharides & $16: 0,18: 2,20: 4,20: 5$ & aspartic acid, threonine, serine & $\begin{array}{l}\beta \text {-carotene, zeaxanthin, } \\
\text { chlorophyll } a\end{array}$ \\
\hline Heterokontophyta & Laminaran & $16: 0,16: 1,20: 5$ & phenylalanine, serine, alanine & $\begin{array}{c}\beta \text {-carotene, } \\
\text { chlorophyll } a / c\end{array}$ \\
\hline Prymnesiophyta & Chrysolaminaran & $16: 0,16: 1,18: 1,18: 2,18: 3,22: 6$ & glutamate, aspartate, histidine & $\begin{array}{c}\beta \text {-carotene, fucoxanthin, } \\
\text { chlorophyll } a / c\end{array}$ \\
\hline Chlorophyta & Starch & $16: 1,16: 2,16: 3,18: 2,18: 3$ & leucine, asparagine, glutamine & $\begin{array}{c}\alpha \text {-carotene, } \beta \text {-carotene, } \\
\text { chlorophyll } a / b\end{array}$ \\
\hline
\end{tabular}

amino acid profile [Becker, 2007; Safi et al., 2014; Samarakoon et al., 2014; Hemplel \& Maier, 2012; Morris et al., 2008].

The protein content in the Cryptophyta Rhodomonas salina is approximately $53 \% \mathrm{dw}$ when it is harvested in logarithmic phase in batch culture; the Cryptomonads contain higher amounts of protein, up to $64 \%$ dry or organic weight, with aspartate, alanine, glutamate, glycine, serine, leucine, and lysine as the major amino acids [Dunstan et al., 2005]. The proteins in Chlorarachniophyta are contained in the pyrenoids and are implicated in playing a central role in carbon fixation and metabolism [Gilson \& McFadden, 1999]. The Euglenophyta Euglena gracilis has a protein content of $39-61 \%$ (dw) [Becker, 2007; Safi et al., 2014; Hempel et al., 2012].

The total soluble protein concentration was measured in cells of different microalgae species such as green algae, Cyanobacteria (blue-green algae), and diatoms with no treatment and by treating with different mechanisms of wall disruption. With no disruption treatment, the protein percentages of dry weight were $11.9 \%$ for Botryococcus braunii, $67.9 \%$ for Chlamydomonas reinhardtii, $42.2 \%$ for Chlorella ellipsoidea, $29.0 \%$ for Chlorella vulgaris, $44.7 \%$ for Micractinium sp., 51.3\% for Microcystis aeruginosa, 33.3\% for Navicula sp., and $70 \%$ for Spirulina platensis. However, depending on the microalgae cell wall characteristics and mechanism of disruption, those percentages can differ [Servaites et al., 2012].

Parameters measured for protein quality include ratio (PER) expressed as the mass gain per unit tested on animals in short-term trials; biological values (BV) giving the proportion of absorbed protein; protein digestibility coefficient (DC), and the net protein utilization (NPU). The method chosen for drying the microalgae has an impact on these parameters but most part of referenced studies observed that they are not far from casein and egg. Also levels of all essential amino acids of various microalgae species are comparable to those of conventional sources of proteins, with the same limiting amino acids as for egg [Barka \& Blecker, 2016].

Novel protein sources such as microalgae can be used as a substitute for meat, legumes, or eggs for vegetarian dishes or as a nutraceutical for pathologies. The microalgal protein and amino acids can also provide beneficial effects as a functional ingredient, while the bioactive peptides resulting from protein hydrolysis may act as molecules with a positive impact by binding or inhibiting specific receptors [Samarakoon et al., 2014]. For example, hydrolysates derived from specific microalgae by enzymatic hydrolysis have been found to possess antioxidant properties [Hu et al., 2015]. Beneficial effects on crypt depth, mucosal protein levels, and jejunal and ileal cell proliferation indexes were observed when crude extracts of Chlorella vulgaris were used in a biological model with anastomosis [Kerem et al., 2008]. In addition, when an enzymatic protein hydrolysate of Chlorella vulgaris was administrated to malnourished mice to improve their nutritional status, there was an increase in free amino acid serum concentration, hemoglobin concentration, and beneficial effects on small-intestine function [Morris et al., 2011].

The peptide derived from the protease hydrolysis of a protein from Nannochloropsis oculata has been shown in vitro to produce nitrates with an inhibitory effect on angiotensin-I-converting enzyme (ACE), which can be used against hypertension and other cardiovascular diseases. The peptides from purified protein hydrolysates from Chlorella vulgaris (Val-Glu-Cys-Tyr-Gly-Pro-Asn-Arg-Pro-Gln-Phe), Spirulina platensis (Ile-Ala-Glu), and Undaria pinnatifida (Ala-Ile-Tyr-Lys) have a similar effect on ACE [Samarakoon et al., 2014]. In addition, the engineered diatom Phaeodactylum tricornutum can synthesize and secrete a human IgG antibody against the hepatitis B virus surface protein [Hempel \& Maier, 2012].

Cyanobacteria such as Microcystis, Anabaena, Nostoc, Spirulina, and Aphanizomenon flos-aquae result in a group of peptides with different biological properties. Cyanovirin-N is a protein from Nostoc ellipsosporum, which inactivates diverse strains of HIV-1. Borophycin, cryptophycin, and lipopeptides are isolated from Nostoc and have cytotoxicity activity against human epidermoid carcinoma, fungicidal activity, and anticancer activities, respectively [Peake et al., 2011]. The blue polypeptide phycocyanin from Spirulina stimulates hematopoiesis, emulates the effect of hormone erythropoietin, and regulates the production of white blood cells [Raja et al., 2008].

\section{LIPIDS}

Microalgae can produce different kinds of lipids such as glycolipids, phospholipids (polar lipids), glycerolipids with neutral storage lipids, and free fatty acids. The lipid content in microalgae varies between $20 \%$ and $50 \%$ (dw). These lipids may be used as energy storage or as energy substrates, as cell membrane structural components, and for metabolic processes such as signal transduction, transcriptional and translational control, cell-cell interactions, secretion, and vesicle 
trafficking. For example, phospholipids are located in extrachloroplast membranes, and glycolipids are found in cellular membranes; triacylglycerols (TAGs) can be found in storage form such as in lipid bodies in the cytoplasm, and in certain green algae such as Dunaliella, they can also be found in the inter-thylakoid space of the chloroplast [Hu et al., 2008; Olofson, 2012; Bellou et al., 2014].

Among the lipids, fatty acids are the major constituent of microalgal biomass, and they can be found in different forms: in the phospholipids that form a phosphate group at position $s n-3$; glycerolipids that have a basic structure based on glycerol esterified at positions $s n-1$ and $s n-2$; and in non-polar glycerolipids, which can be esterified at one (monoacylglycerol), two (diacylglycerol), or three positions (TAG). The de novo synthesis of fatty acids occurs primarily in the chloroplast, where 16- or 18-carbon fatty acids are produced. To create an unsaturated fatty acid, a double bond is introduced by the soluble enzyme stearoyl-acyl carrier protein desaturase. Elongation is terminated, and then in the chloroplast, they are transferred to glycerol-3-phosphate with the formation of TAG, which is also coordinated with secondary carotenoids ( $\beta$-carotene, lutein, or astaxanthin) that are esterified with TAG and sequestered into cytosolic lipid bodies. However, there are reports that the biosynthesis of polyunsaturated fatty acids (PUFAs) could differ between species. In the red microalga Porphyridium cruentum, 18:2 is first desaturated to 18:3 $\omega-6$, and then to 20:5 $\omega-3$, while in Euglena, 18:2 is elongated to 20:2 before desaturation; there may be four different pathways for eicosapentaenoic acid (EPA) production in Phaeodactylum tricornutum [Hu et al., 2008; Khozin-Goldberg et al., 2002; Ohlrogge \& Browse, 1995; Bellou et al., 2014].

There are also microalgae, referred to as oleaginous algae, that can produce substantial amounts of TAG. The term oleaginous is used to describe the algae capable of accumulating large quantities of oil, $>20 \%$ (weight) of their biomass (e.g., Chlorella sp., Nannochloropsis sp.), which can be up to $80 \%$ of the dry biomass [Bellou et al., 2014].

However, the amount of lipids and the number or position of double bonds on the carbon chain can vary according to the algal species and growing conditions. Optimal conditions can promote fatty acid esterification into glycerol-based membrane lipids, while unfavorable conditions can increase the formation of neutral lipids such as TAG due to their storage and energy activity [Hu et al., 2008]. In general, many microalgae have PUFAs such as arachidonic acid (AA), eicosapentaenoic acid (EPA), and docosahexaenoic acid (DHA). The major saturated fatty acid is palmitate [Guschina \& Harwood, 2006].

Cyanobacteria can contain saturated fatty acids, monoenoic fatty acids, and unsaturated fatty acids. Palmitic acid (16:0) and oleic acid (18:1) are the major fatty acids in all Cyanophyceaen members. Spirulina, representing the most characteristic Cyanobacteria, produces linoleic and $\gamma$-linolenic acids [Maslova et al., 2004; Chaiklahan et al., 2008; Sahu et al., 2013]. The Rhodophyta have the highest proportion of total fatty acid content, with about $81 \%$ of its strains having EPA and arachidonic acid [Lang et al., 2011]. Porphyridium cruentum, one of the most representative of the red microalgae, has an average of $11 \%$ total lipids, which can be composed of 16:0, 18:2 $\omega-6,20: 4 \omega-6$, and 20:5 $\omega-3$ [Rebolloso-Fuentes et al., 2000].

In the Heterokontophyta, the Bacillariophyta have neutral lipids, glycolipids, and phospholipids. They also contain tetradecanoic acid, hexadecanoic acid, palmitoleic acid, and EPA as the predominant fatty acids. The main raw materials are triglycerides such as monogalactosyl, diagalactosyl, sulfoquinovosyl diglyceride, phosphatidyl glycerol, phosphatidyl choline (lecithin), and phosphatidyl ethanolamine. Palmitoleic, palmitic, eicosapentaenoic, and eicosatetraenoic acids are the major fatty acids. The diatom Chaetoceros gracilis includes linoleic acid, $\alpha$-linolenic acid, arachidonic acid, eicosapentaenoic acid, and docosahexaenoic acid. It can also produce monounsaturated fatty acids and saturated fatty acids such as oleic acid and palmitic acid, respectively. Phaeodactylum tricornutum is the diatom with a potential for the production of EPA, palmitoleic acid, palmitic acid, hexadecatrienoic acid, and myristic acid [Hu et al., 2008; Domergue et al., 2003; Ramachandra et al., 2009]. The most characteristic Eustomatophyta is Nannochloropsis, which has been shown to have palmitic acid, palmitoleic acid, oleic acid, eicosatetraenoic acid, and EPA as its major fatty acids. They also contain saturated fatty acids (21-50.8\%) and monounsaturated fatty acids (34-52\%). The fatty acids 16:0, 16:1, $18: 1,20: 5,22: 5$, and 22:6 can be found in Chrysophyta [Hu et al., 2008; Ma et al., 2014].

Prymnesiophyta microalgae contain such fatty acids as 16:0, 16:1, 18:1, 18:2, 18:3, and 22:6. Isochrysis galbana can produce an accumulation of 14:0, 16:0, 16:1, 18:4, 20:5, and 22:6 [Hu et al., 2008; Bandarra et al., 2003] under both $24 \mathrm{~h}$ and $8 \mathrm{~h}$ lighting conditions. In contrast, the major fatty acids in green microalgae are reportedly 16:1, 16:2, 16:3, 18:2, and 18:3. The most widely studied oleaginous microalgal species belong to Chlorophyta (green algae). About $10 \%$ of the fatty acid content in Chlorella sp. is 14:0, whereas freshwater algae contain no more than $1 \%$. Other fatty acids present include 16:0, 16:1, 16:2, 16:3, 18:0, 18:1, 18:2, and 18:3. However, the quantity of $\gamma$-linolenic acid in the different concentrations could be affected by cultivation conditions [Petkov \& García, 2007].

Cryptophyta strains in the logarithmic phase possess from 78-87\% total lipids, as well as sterols and fatty acids (16:0, 20:1, 18:3, 18:4, 20:5). The microalga Rhodomonas salina may be useful for its saturated $(14: 0,16: 0,18: 0)$, monounsaturated $(16: 1 \omega-9,18: 1 \omega-7,18: 1 \omega-9)$, and polyunsaturated (18:2 $\omega-6,18: 3 \omega-3,18: 4 \omega-3,20: 5 \omega-3,22: 6 \omega-3)$ fatty acid content [Hu et al., 2008; Dunstan et al., 2005; Guevara et al., 2011]. Roche \& Leblond [2010] reported that Chlorarachniophyta contains betaine lipids, while Leblond et al. [2010] observed that four organisms from three genera contained fatty acids, glycolipids, and triacylglycerol, with a dominant fraction of 16:0 and 22:5 $\omega-3$.

The Glaucophyta have been characterized for their two major plastid lipids, mono- and digalactosyldiacylglycerol, associated mainly with the fatty acids hexadecanoic acid (16:0) and EPA (20:5 $\omega-3)$, which are also found in photosynthetic membranes [Leblond et al., 2010]. Lang et al. [2011] showed that strains of Glaucophyta (including Glaucocystis nostochinearum and Cyanophora paradoxa) had a major pro- 
portion of EPA, with smaller proportion of arachidonic acid. Euglenophyta microalgae have fatty acids such as 16:0, 18:1, 18:2, and 18:3. Euglena gracilis produced myristic, palmitic, oleic, linolenic, arachidonic, and eicosapentaenoic acids in both photoautotrophic and heterotrophic culture and during the logarithmic phase. In addition, 15-, 12- and 5-HETE (hydroxyeicosatetraenoate) has been identified [Hu et al., 2008; Guschina \& Harwood, 2006; Hulanicka et al., 1964].

The importance of algal lipids lies in their commercial value as an alternative nutritional source to generate functional foods from their PUFAs such as EPA and DHA and their precursor alpha-linolenic acid. The human diet impacts health, because the types of fatty acids consumed can vary the lipid rafts within cell membranes, affecting signaling molecules and the interaction between cell types, especially within the immune system [Ryckebosch et al., 2012].

The fatty acids DHA and EPA participate in immune system activity by reducing the expression of monocyte chemoattractant protein 1 and interleukin 8 , which are activated by the peroxisome proliferator-activated receptor $\alpha$ and inhibit nuclear factor $\kappa \mathrm{B}$. This is due, in part, to the preferential formation of the 5-series eicosanoids, which are less potent chemoattractants than the 4-series eicosanoids derived from arachidonic acid. It has also been reported that adipocytes treated with DHA express more anti-inflammatory interleukin 10 in comparison to untreated cells. Metabolically, these fatty acids can modulate lipid pathways, promoting lipolysis and fatty acid oxidation and inhibiting lipogenesis [Peake et al., 2011; Tai \& Ding, 2010].

$\Omega-3$ and $\omega-6$ fatty acids are also be found in the lipid bilayer of cell membranes and are important for maintaining membrane fluidity. In the nervous system, PUFAs are released via neurotransmitter stimulation and metabolized into active compounds such as prostaglandins and leukotrienes, among others. The relationships between $\omega$-3 consumption and depressive symptoms as well as cognitive and physiological development have also been investigated. In addition, clinical trials with DHA-rich oil indicate efficacies comparable to fish oil for protection from heart disease and dyslipidemia [Ryckebosch et al., 2012; Giles et al., 2013].

Spirulina contains $\gamma$-linolenic acid, which can aid in heart disease, depression, and inflammatory diseases such as arthritis; its $\beta$-carotene has been reported to have antioxidant, anti-inflammatory, and protective activities against singlet oxygen-mediated lipid peroxidation [Deng \& Chow, 2010; Kulshreshtha et al., 2008]. In contrast, the diatom Phaeodactylum tricornutum Bohlin contains an antibacterial fatty acid EPA against Staphylococcus aureus, Bacillus cereus, and the Gram-negative marine bacteria Listonella anguillarum [Desbois et al., 2009]. This diatom also contains two monogalactosyldiacylglycerols with the capacity to induce apoptosis in two genetically-matched immortal mouse epithelial cell lines, as well as other anticancer activities [Samarakoon et al., 2014].

Nannochloropsis oculata has been used as a source of EPA conjugated with phospholipids in humans; even this microalga can be considered as an alternative vegetarian source of $\omega$-3 fatty acids [McHugh, 2013]. The DHA-rich marine microalga Schizochytrium mangrovei showed activity in vitro on the vitality of healthy pheochromocytoma cells, and it displayed neuroprotective activity and extended the life span of wild-type and mutant fruit flies (Drosophila melanogaster) [Huangfu et al., 2013].

\section{CARBOHYDRATES}

The chemical composition of microalgae is important for their biological functions and potential uses. Microalgae have higher quantities of lipids and proteins than carbohydrates. Despite the low content (approximately 10\% of dry matter) the carbohydrates could be used as a functional food, although the carbohydrate biomass depends on the microalgal species (e.g., Porphyridium cruentum 40-57\%; Spirogyra sp. 33-64\%) [Markou \& Nerantizis, 2013; Mairet et al., 2014].

Microalgal carbohydrates are formed both inside the chloroplast and in the cytosol, and their presence in the microalgal cell wall and intracellular vacuoles provides energy in the form of monosaccharides or polymers [Becker, 2007]. The most abundant monomers are glucose, rhamnose, xylose, and mannose, and while the polymers vary in size (di-, oligo-, and polysaccharides) and composition, they lack hemicellulose and lignin. The content and type of carbohydrates depend on the microalga; for example, Cyanobacteria have a four-layered cell wall (Gram-negative type), and their lack of cellulose facilitates human consumption. Their cell inclusions have glycogen granules, usually $\alpha$-1,4-linked glucan with frequent side chains through $\alpha-1,6$-linked glucosyl residues, although a few have a different $\alpha$-polyglucan known as semi-amylopectin [Gómez-Casati et al., et al., 2003; Nakamura et al., 2005]. In contrast, eukaryotic microalgae have a cell wall composed of a microfibrillar layer of cellulose surrounded by an amorphous layer that may be silicified or calcified and strengthened with plates and scales. There are also naked microalgae that lack cell walls, and some microalgae may have a laminated polysaccharide investment. The production of polysaccharides can also vary (e.g., carragenin, sulfated polysaccharides); for example, the cyanobacterium Arthrospira platensis has a fragile cell wall that is composed primarily of murein and lacks cellulose [Safi et al., 2014; Tomaselli, 2004].

The Rhodophyta, or red algae, include macroalgae and a few species of microalgae. The macroalgae cell walls are composed of a microfibrillar layer of cellulose and amorphous polysaccharidic mucilages (agar or carragenins), while red microalga such as Porphyridium are encapsulated by a polysaccharide in the gel state and composed of sulfated polysaccharides. These sulfated polysaccharides have a basic block that comprises the aldobiouronic acid 3-O-( $\alpha-\mathrm{D}$ -glucopyranosyluronic acid)-L-galactopyranose disaccharide, which is a part of a bigger structure composed of the linear building block that contains (1-2)- or (1-4)-linked xylopyranosyl, (1-3)-linked galactopyranosyl, and (1-3)-linked glucopyranosyl or glucopyranosyluronic acid residues. Red microalgae have storage granules of floridean starch, an $\alpha-1,4$ glucan, a starch hybrid, and glycogen, although some species could have amylose [Pulz \& Gross, 2004; Tomaselli, 2004; Arad et al., 1985; Geresh et al., 2009; Shimonaga et al., 2008]. 
The Heterokontophyta microalgae, also called brown algae, have a polysaccharide storage product called laminaran ( $\beta$-1,3-linked glucan with 1,6 linkages), especially in the Phaeophyceae. Diatoms differ by lacking a terminal mannitol residue at the reducing end of the polysaccharide, and it is therefore referred to as chrysolaminaran (also called leucosin) [Pulz \& Gross, 2004; Chiovitti et al., 2004]. These polysaccharides may differ from other algal species in their grade of polymerization. The cell wall can also vary, because it is often lacking or composed of cellulose. They can also have silicified scales, polysaccharidic envelopes, and exopolysaccharide-sulfated polysaccharides such as fucoidans (sulfated $\alpha$-L-fucose residues). For example, Nannochloropsis is endowed with recalcitrant cell walls that contain algaenans and cellulose, while diatoms have siliceous cell walls and exude polymers [Tomaselli, 2004; Gelin et al., 1996; Wutsman et al., 1997].

The class Prymnesiophyta contains water-soluble $\beta-1,3-$ -glucan with an essentially linear $\beta$-D-1,3-glucan backbone and some branching at position 6 or 2 . These glucans can be classified as laminaran, paramylon, or chrysolaminaran and are distinguished based on chain length and the presence of mannitol end groups. However, chrysolaminaran has been characterized as the principal storage glucan. Some have cell walls covered with circular body scales embedded in a mucus matrix-like mucilage, and others, such as Prymnesiophyta, are calcified (cocoliths) by different types of biomineralization [Alderkamp et al., 2007; Hirokawa et al., 2008]. The green microalgae (Chlorophyta) have cellulose in their cell wall and use a starch ( $\alpha$-1,4-linked glucan) composed of amylose and amylopectin as their storage product. However, Chlorella, one of the most studied green microalga, has a diverse cell wall composition and structure among the different strains. Some Chlorella strains have a cell wall with a trilaminar (TLS) outer layer that contains algaenan, a resistant and non-hydrolysable biopolymer, while other strains have a cell wall with no TLS outer layer, but a high percentage of polysaccharides. In contrast, the Chlorophyta Dunaliella salina lacks a rigid cell wall [Busi et al., 2014; Oren, 2005, Chen et al., 2011].

Chlorarachniophyta are marine amoeboflagellate unicells that harbor green algal endosymbionts that have lost many subcellular structures (mitochondria and cell walls) and have a small nucleus-like structure called a nucleomorph that is housed within a vestige of cytoplasm. The other significant structure is a green chloroplast, which may manufacture carbohydrates and other compounds. However, some are naked spherical cells, whereas others are coccoid cells with single- or multi-layered cell walls. Chlorarachniophyte cells store long chain $\beta-1-3$-glucan within a vacuole in the host cell cytoplasm appressed to the chloroplast bulbous pyrenoid [McFadden et al., 1997; Hirokawa et al., 2008; Gilson \& McFadden, 1999].

The Chryptophyta microalgae do not possess a cell wall; instead they have a periplast, and some produce extracellular polysaccharides, which could result in starch grains formed near the pyrenoid. The Glaucophyta also accumulate starch in the cytosol and lack a cell wall; instead, with the exception of Glaucosphaera sp., they possess inclusions termed cyanelles surrounded by peptoglycan [Ball et al., 2011; Lichtlé, 1979; Paulsen et al., 1992]. The Euglenophyta has a proteinaceous outer cover called a pellicle and paramylon as a reserve carbohydrate ( $\beta$-1,3-polyglucan), which is called paramylon starch [Pulz \& Gross, 2004].

Microalgal polysaccharides can vary in their biological properties depending on their characteristics. For example, beta glucans are considered immune stimulators, cellulose and starch can act as dietetic fibers, and sulfated polysaccharides have antioxidant and antitumoral activities. Beta glucans are polysaccharides with glucose as structural components, with $\beta$-1,3- or $\beta$-1,4-linear linkages that are connected by $\beta-1,6$ linkages. Both have been reported to have activity as a dietary fiber; however, the $\beta-1,4$ form does not exhibit immune modulatory effects. In contrast, when $\beta$-1,3-glucans are consumed, they can bind specific gastrointestinal dendritic cell (DC) receptors, which can lead to an immune response that promotes the activation of phagocytosis, radical oxygen species production, and a cellular immune response. There is also a correlation between immune response and the size, conformation, molecular weight, and branching frequency of the glucans [Chen \& Seviour, 2007; Stier et al., 2014; Wismar et al., 2011].

It has been reported that the polysaccharides of the unicellular green alga Chlorella sorokiniana can mature dendritic cells and induce interleukin 12 (IL12) secretion, which activates natural killer cells (NKs) and leads to the differentiation of T helper cells into Th1 cells. This is important against viral infection and cancer [Chou et al., 2012]. A preparation containing brown algae laminarin (1,3:1,6- $\beta$-glucans) provides protection against irradiation and bacterial pathogen infection by increasing the proliferation of $\mathrm{B}$ cells and $\mathrm{T}$ helper cells. Laminarin can also modulate the response to systemic infection and hepatic inflammation [Neyrinck et al., 2007; Kraan, 2012]. Fucoidan and paramylon have been reported to enhance the phagocytic and secretory activity of macrophages and induce the production of interleukins (IL-6, IL-1) and TNF- $\alpha$. In addition, the paramylon extracted from Euglena gracilis exerts antioxidant protective action following acute hepatic injury in rats [Bianchi et al., 2015; Lee et al., 2012].

Sulfated polysaccharides (SPs) have demonstrated diverse biological activities. For example, fucoidans are sulfated fucosylated polymers that exhibit the properties of heparin/ heparan sulfate and the capacity to control parameters involved in connective tissue destruction in human skin. Studies have indicated that the SPs of the red microalga Porphyridium have antiviral and antioxidant activity, while those from Phaeodactylum and Chlorella have anti-inflammatory activity [Raposo et al., 2013; Senni et al., 2006]. Sulfated polysaccharides, as well as cellulose and other beta glucans, can also be considered dietary fiber, which is not digested, but rather fermented by intestinal bacteria to produce short-chain fatty acids; these have been recognized as mediators in intestinal immune function. Dietary fiber can also regulate energy intake, improve glycemic control, and diminish serum lipids [Lattimer \& Haub, 2010; Vinolo et al., 2011]. Spirullina has lipid and glucose metabolism activity in experimental animals and diabetic patients, while Porphyridium sp. polysaccharides (50-70\% of the biomass) are associated with hypocholesterolemic effects in rats. Chlorella and Spirullina polysaccharides have an inhibitory effect on the adhesion of Helicobacter pylori 
to gastric mucin [Loke et al., 2007; Dvir et al., 2009; Khan et al., 2005], and Isochrysis galbana has displayed beneficial gastrointestinal effects in diabetic rats [Nuño et al., 2013].

\section{PIGMENTS AND VITAMINS}

Microalgae possess pigments that are found as carotenoids (orange coloration), xanthophylls (yellowish shade), phycobilins (red or blue coloration), and chlorophylls (green coloration). Carotenoid and chlorophyll content is generally higher in microalgae than in some plants. In addition, they contain other valuable antioxidants such as $0.01-3 \%$ tocopherols (vitamin E), 0.1-1.5\% ascorbic acid (vitamin C), and phenolic compounds [Koller et al., 2014; Mulders et al., 2013].

The carotenoids can be reserved in oil droplets in either the chloroplast stroma or the cytosol, depending on the microalga. When microalgae grow under optimal conditions, these carotenoids are usually present in low concentration $\left(0.5 \% \mathrm{gg}^{-1} \mathrm{dry}\right.$ weight$)$, although some chlorophytes can reach up to $10 \% \mathrm{gg}^{-1}$ dry weight when cultivated under adverse growth conditions, as is the case for Dunaliella salina [Mulders et al., 2013]. Carotenoids play a role in oxygenic photosynthesis, as a direct quencher of reactive oxygen species, and in the thermal dissipation of excess energy in the photosynthetic apparatus. Xanthophylls are the oxidation products of carotenes; in the xanthophyll cycle, they bring about the rapid conversion of violaxanthin into zeaxanthin [García-Mendoza \& Pacheco-Ruiz, 2006]. Phycobilins (phycocyanin and phycoerythrin) are found in the stroma of the chloroplasts of Cyanobacteria, Rhodophyta, Glucophyta, and some cryptomonads and are often used as food colorants [Koller et al., 2014].

On the other hand, chlorophyll has two main types: chlorophyll $a$ is the principal active photochemical blue/ green pigment with an absorbance from 660 to $665 \mathrm{~nm}$, and it functions as a light receiver for driving photosynthesis; chlorophyll $b$ is a green/yellow pigment with a maximum absorbance of $642-652 \mathrm{~nm}$. There is a chlorophyll $c$, which has a fully unsaturated porphyrin macrocycle and generally lacks chlorophyllides [Hosikian et al., 2010; Su et al., 2008].

Carotenoids and chlorophyll are the major pigments in microalgae and their concentrations can vary. For example, Cyanobacteria can have a higher concentration of $\beta$-carotene, zeaxanthin, echinenone, myxol glycosides, and chlorophyll $a$; the Glaucophyta and Rhodophyta microalgae contain $\beta$-carotene, zeaxanthin, and chlorophyll $a$; the Cryptophyta class contains $\alpha$ carotene, chlorophyll $a$, and chlorophyll $c$; Prymnesiophyta has $\beta$-carotene, diadinoxanthin, fucoxanthin, chlorophyll $a$, and chlorophyll $c$; Euglenophyta and Chlorarachniophyta have $\beta$-carotene, chlorophyll $a$, and chlorophyll $b$; green microalgae contain $\alpha$-carotene, $\beta$-carotene, neoxanthin, violaxanthin, lutein, chlorophyll $a$, and chlorophyll $b$; and most of the Heterokontophyta class has $\beta$-carotene, chlorophyll $a$, and chlorophyll $c$, with some variation such as the diatoms and the Chrysophyta microalgae, which also contain fucoxanthin, and the Eustigmatophyta, which has violaxanthin and no chlorophyll $c$ [Obata \& Taguchi, 2012; Takaichi, 2011].
Microalgae also represent a valuable source of vitamins such as A, B1, B2, B6, B12, C, E, nicotinate, biotin, folic acid, and pantothenic acid. For example, Isochrysis galbana is an important source of vitamins A and E, folic acid, nicotinic acid, pantothenic acid, biotin, thiamin, riboflavin, pyridoxine, cobalamin, chlorophyll ( $a$ and $c$ ), fucoxanthin, and diadinoxanthin, while Euglena gracilis $Z$ can produce antioxidant vitamins such as $\beta$-carotene and vitamins $\mathrm{C}$ and $\mathrm{E}$ [Mulders et al., 2013; Countinho et al., 2006; Takeyama et al., 1997].

The importance of pigments in health is related to their bioavailability and bioactivities. It has been suggested that the algal carotenoids can be metabolized if they are administrated orally, especially dietary fucoxanthin (the most abundant carotenoid), because it is deacetylated into fucoxanthinol in the intestinal tract by lipase and pancreatic esterase or in the intestinal cells for incorporation within the circulatory system [Peng et al., 2011]. It has been reported that fucoxanthin, carotene, and astaxanthin also have antioxidative and antiobesity activity. One study with $0.5 \%$ fucoxanthin in high fat-fed mice demonstrated their anti-obesity effect, showing a reduction in epididymal adipocyte size and a decrease in mRNA expression of the lipid-regulating enzymes [Mulders et al., 2013; Peng et al., 2011]. Dunaliella salina is a microalga with a high mass production of $\beta$-carotene (up to $14 \% \mathrm{dw}$ ), which in the lyophilized form can reduce fibrosarcoma in Wistar rats. While Dunaliella barbawil promotes the growth of normal mammary gland cells, it also inhibits neoplastic cells due to the antioxidant effect of carotene. The authors suggest that the bioactive astaxanthin and xanthophylls in Chlorella ellipsoidea could be potential therapeutic agents in the prevention of human cancers [Raja et al., 2008; Lordan et al., 2011].

Lutein, one of the major carotenoids, is present in Chlorella minutissima and could have a potential use in the prevention and treatment of diseases such as cataracts, macular degeneration, atherosclerosis, and different types of cancer [Dineshkumar et al., 2015]. The carotenoids that accumulate in microalgae can also be used as antioxidant molecules with the capacity to quench free radicals, thereby protecting cells and tissues from oxidative damage, and even preventing food deterioration [deMello-Samapayo et al., 2013].

Chlorophyll can be used as a pharmaceutical product for its healing activity and its chemical structure, which is similar to hemoglobin, as well as for its capacity to stimulate tissue growth through the rapid interchange of carbon dioxide and oxygen. Because of these characteristics, chlorophyll has been used in pathologies such as chronic ulcer and oral sepsis. Hematococcus pluvialis contains antioxidants such as chlorophyll and astaxanthin, whose protective activities can be used against cancer, inflammation, and other pathologies [Hosikian et al., 2010; Lordan et al., 2011]. The cyanobacteria Aphanizomenon flos-aquae has a hypocholesterolemic effect due to its chlorophyll content, which stimulates the liver [Singh et al., 2005].

\section{CULTURE AND BIOCHEMICAL COMPOSITION}

The biochemical composition in microalgae can be influenced by the environmental conditions of the culture. With 
the exception of diatoms, most species of microalgae undergo mitosis during a defined interval relative to the light:dark cycle, and there are imposed changes in the cellular contents of proteins, carbohydrates, lipids, and pigments. When cultures were under a $12 \mathrm{~h}$ light: $12 \mathrm{~h}$ dark cycle, it was observed that no nitrogen was assimilated at night, and carbon was preferentially consumed over lipids. The macronutrients and pigments were accumulated during the light period, especially during the first hour of the light cycle [Fábregas et al., 2002].

Nutrient limitations in cultures, especially nitrogen deprivation, can reduce protein synthesis, increase carbohydrate production, and enhance the storage of polysaccharides; however, they can also inhibit cell division and photosynthesis or lead to a reduction of algal biomass [Song et al., 2013]. Macronutrients can show negative correlations, such as that between protein content and carbohydrate and lipid content [Kadkhodeaei et al., 2015; Markou et al., 2012]. Under nutrient limitation, the total lipid content can be in excess of $40 \%$. Nitrogen limitation in cultures has been related to an increase in lipid production, especially TAGs containing saturated and monounsaturated fatty acids. In general, high irradiances and nutrient limitation (nitrogen or P) lead to an increase in the size of the lipid fraction and stimulate TAG accumulation; meanwhile under low irradiances, mainly polar lipids (phospholipids and glycolipids) accumulate, which are structurally and functionally associated with cell membranes. However, cellular growth declines. There are exceptions, such as diatoms, whose long-phase lipid content does not respond to nitrogen starvation [Rodolfi, 2009].

Nutrient stress also results in the generation of free radical species in the cell and in changes in the antioxidant content. Primary carotenoids (chlorophylls, $\beta$-carotenoids, violaxanthin, and vaucheriaxanthin) are synthesized under normal, favorable growth conditions in microalgae, especially in $E u$ stigmatophyceae strains. However, secondary carotenoids are produced under nitrogen-depleted stress conditions and synthesized from primary carotenoids; they also accumulate outside the chloroplast after the cell growth phase [CamachoRodríguez et al., 2015; Goiris et al., 2015]. Under intense light exposure, microalgae display photodamage, and some become pale green and are reduced in size, indicating a decrease in chlorophyll density and cell development effects. The carotenoids do not show these effects, but instead, have induced biosynthetic expression [Nurachman et al., 2015]. In addition, in excess light, violaxanthin is interconverted into zeaxanthin by the removal of epoxides via the mono-epoxy carotenoid antheraxanthin. Zeaxanthin is epoxidized under low light conditions, and nitrogen deficiency promotes the accumulation of the pigment astaxanthin in some microalgae such as Haemotococcus pluvialis [Camacho-Rodríguez et al., 2015; Müller et al., 2001].

It has been suggested that nutrient content can change depending on the age of the culture; for example, total lipid content and concentration are higher in the late stationary growth phase, but in C. calcitrans, the amount of EPA is higher during logarithmic growth [Miller et al., 2014]. It has therefore been suggested that to obtain higher lipid concentrations, the recovery of the biomass could be done during the low-growth state. The harvesting methods such as centrifugation, filtration, sedimentation, and flocculation that are used to obtain the biomass are suitable for every case or species of microalga. Centrifugation can concentrate biomass in a short time and maintain the viability of the cells; however, the operational costs can increase during the production of the cultures. Filtration is slower than centrifugation, but equally expensive. Sedimentation and flocculation are other methods, but they do not work for every microalga and depend on light conditions and growth rate (daylight and the exponential phase can retard the agglomeration rate); in addition, some flocculants could change the cell composition [Chacón-Lee \& GonzálezMariño, 2010]. The procedure for biomass preservation for subsequent compound extraction can also alter the cell composition; for example, after suspension and centrifugation, microalgae can be frozen or sprayed during drying, which does not lead to significant lipid oxidation since spray drying causes a loss of carotenoids. When lipids are extracted from microalgal biomass with specific solvents, the lipid classes could differ, and some other component could be co-extracted [Chacón-Lee \& González-Mariño, 2010; Ryckebosch et al., 2012]. Therefore, the culture conditions, growth phase, and harvesting method must all be considered to obtain the appropriate types and quantities of microalgal compounds.

\section{FOODOMICS AND MICROALGAL BIOACTIVE COMPOUNDS}

The consumption of microalgal bioactive compounds can have both beneficial and adverse effects. To identify such responses, a discipline called foodomics could help to study the food and nutrition domains through the combined application of advanced -omics technologies, techniques, and bioinformatics. Such an investigation can be done from several, but collective, perspectives such as nutrigenomics (gene expression), nutriproteomics (protein synthesis), nutritranscriptomics (mRNA synthesis), and metabolomics (metabolite production) with their respective mathematical and statistical modeling. Likewise, the characterization and quantification of these bioactive ingredients and biomarkers (mRNA, protein, and metabolite concentration) provide indicators of the molecular and cellular events within biological systems, which can be useful measures to provide a link between exposure to the bioactive compound and a health outcome [Herrero et al., 2012; Agrawal et al., 2013].

Several techniques can be used to understand the functional activity. For example, in proteomics, the combinatorial peptide ligand library (CPLL) technique can identify low quantities of proteins (peptides) in food and biological extracts. The procedures include analyzing the metabolomic/ proteomic applications of the bioactive compounds (peptides, proteins, lipids, sterols, carbohydrates, or vitamins) in human biofluids, or for their identification in food, gas chromatography, liquid chromatography, high performance liquid chromatography, capillary electrophoresis, and two-dimensional electrophoresis coupled to mass spectrometry can be used. In addition, mass spectrometry can be used to study metabolomics and analyze the metabolites, proteins, and peptides 
of interest produced in large-scale, for amino acid sequencing, which can subsequently be used for protein identification. Mass spectrometry is also useful when there is no prior knowledge of the proteins and works through the mass analyzers time-of-flight, quadrupole, Fourier transform ion cyclotron resonance, ion trap, Fourier transform infrared spectroscopy, coupled plasma, and electrospray ionization, which can be combined in one mass spectrometer with a dynamic range of up to four orders of magnitude. The determination of geometric structures is done using nuclear magnetic resonance or X-ray crystallography, and collision-induced dissociation is used to obtain the fragmentation pattern of the peptides/ protein [Chacón-Lee et al., 2010; Chen, 2008; Bernal et al., 2014].

The genomic and transcriptomic approach to understanding how the molecular mechanisms are related to the influences of diet can be observed with DNA microarray analyses, which label nucleotides representing the mRNA population of interest that are then used with a large collection of gene probes. Microarrays can be classified into the types of DNA displayed on the platform, complementary DNA or oligonucleotides. To confirm the microarray data, regulated genes are validated by quantitative reverse transcriptase-PCR with housekeeping genes monitored for stability [Kato et al., 2005]. There is also a microRNA (miRNA) microarray that can be used to investigate miRNA expression to understand changes in the regulation of cellular activities when the cell is exposed to functional foods. When the microarray is completed, the bioinformatics analysis must be performed using the Gene Ontology and the Kyoto Encyclopedia of Genes and Genomes databases to interpret the functions of the targeted genes [Liu et al., 2015].

In addition to microarrays, there are also sequencing-based techniques that count DNA fragment tags to provide a digital representation of the gene expression level, including the serial analysis of gene expression technique. The expression of individual genes can be determined by quantifying the mRNA using northern blotting or real-time PCR [Sharkey et al., 2004; Cimica et al., 2007]. New technologies include useful tools for public health professionals that allow them to use genetic information to identify different responses to diet by population subgroups and to develop products that benefit the state of health.

\section{CONCLUSIONS}

Microalgae and their bioactive compounds are already applied in the nutrition field as a tool for pathology therapy. The future of microalgae as functional foods and the use of their biomolecules as functional ingredients relies on the diversity of the microalga species, the different compounds they contain, and the capacity to increase biomass concentration and certain nutrients during cultivation. Nevertheless, it is necessary to increase clinical research to understand their different biological effects and ensure their safety.

\section{CONFLICT OF INTEREST}

The authors declare no conflict of interest.

\section{REFERENCES}

1. Agrawal G.K., Timperio A.M., Zolla L., Bansal V., Shukla R., Rakwal R., Biomarker discovery and applications for foods and beverages: Proteomics to nanoproteomics. J. Proteomics, 2013, 93, SI, 74-92.

2. Alderkamp A.C., Buma A.G.J., Van-Rijssel M., The carbohydrates of Phaeocystis and their degradation in the microbioal food web. Biogeochemistry, 2007, 83, 99-118.

3. Arad S., Adda M., Cohen E., The potential of production of sulfated polysaccharides from Porphyridium. Plant Soil, 1985, 89, 117-127.

4. Ball S., Colleoni C., Cenci U., Raj J.N., Tirtiaux C., The evolution of glycogen and starch metabolism in eukaryotes gives molecular clues to understand the establishment of plastid endosymbiosis. J. Exp. Bot., 2011, 62, 1775-1801.

5. Bandarra N.M., Pereira P.A., Bautista I., Vilela M.H., Fatty acids, sterols and $\alpha$-tocopherol in Isochrysis galbana. J. Food Lipids, 2003, 10, 25-34.

6. Barka A., Blecker C., Microalge as a potential source of singelcell proteins. A review. Biotechnol. Agron. Soc. Environ., 2016, 20, 427-436.

7. Barsanti L., Coltelli P., Evangelista V., Frassanito A.M., Passarelli V., Vesentini N., Gualterieri, P., The World of Algae. 2008, in: Algal Toxins: Nature, Ocurrence, Effect and Detection (eds. V. Evangelista, L. Barsanti, A.M. Frassanito, V. Passarelli, P. Gualtieri). Springer Science \& Business Media B.V., pp. 281-304. DOI 10.1007/978-1-4020-8480-5_1.

8. Bartsch I., Wiencke C., Bischof K., Buchholz C.M., Buck B.H., Eggert A., Feuerpfeil P., Hanelt D., Jacobsen S., Karez R., Karsten U., Molis M., Roleda M.Y., Schumann R., Schubert H., Valentin K., Weinberger F., Wiese J., The genus Laminaria sensu lato: recent insights and developments. Eur. J. Phycol., 2008, 43(1), 1-86.

9. Becker E.W., Micro-algae as a source of protein. Biotechnol. Adv., 2007, 25, 207-210.

10. Bellou S., Baeshen M., Elazzazy A.M., Aggeli D., Sayegh F., Aggelis G., Microalgal lipids biochemistry and biotechnological perspectives. Biotechnol. Adv., 2014, 32, 1476-1493.

11. Bernal J., Mendiola J.A., Ibáñez E., Cifuentes A., Advanced analysis of nutraceuticals. J. Pharm. Biomed. Anal., 2014, 55, SI, 758-774.

12. Bianchi V.A., Castro J.M., Rocchetta I., Nhabedian D.E., Conforti V., Luquet C.M., Long-term feeding with Euglena gracilis cells modulates immune responses, oxidative balance and metabolic condition in Diplodon chilensis (Mollusca, Bivalva, Hyriidae) exposed to living Escherichia coli. Fish Shellfish Immunol., 2015, 42, 367-378.

13. Brown M.R., Jeffrey S.W., Biochemical composition of microalgae from the green algae classes Chlorophyceae and Prasinophycae. 1. Amino acids, sugars and pigments. J. Exp. Mar. Biol. Ecol., 1992, 161, 91-113.

14. Busi M.V., Barchiesi J., Martín M., Gómez-Casati D.F., Starch metabolism in green algae. Starch-Stärke, 2014, 66, 28-40.

15. Camacho-Rodríguez J., Cerón-García M.C., Fernández-Sevilla J.M., Molina-Grima E., Culture conditions on biomass and hight value product generation by Nannochloropsis gaditana in aquaculture. Algal Res., 2015, 11, 63-73.

16. Chacón-Lee T.L., González-Mariño G.E., Microalgae for "Healthy" Foods-Possibilities and -Possibilities and Challenges. Compr. Rev. Food Sci. Food Safety, 2010, 9, 655-675. 
17. Chaiklahan R., Chirasuwan N., Loha V., Bunnag B., Lipid and fatty acids extraction from the Cyanobacteria Spirulina. ScienceAsia, 2008, 34, 299-305.

18. Chen C.H., Review of a current role of mass spectrometry for proteome research. Anal. Chim. Acta, 2008, 624, 16-36.

19. Chen J., Seviour R., Medicinal importance of fungal $\beta-(1-3)$, (1-6)-glucans. Mycol. Res., 2007, 111(6), 635-652.

20. Chen Y.S., Zheng Y., Labavitch J.M., VanderGheynst J.S., The impact of cell wall carbohydrate composition on the chitosan flocculation of Chlorella. Process Biochem., 2011, 46(10), 1927-1933.

21. Chiovitti A., Molion P., Crawford S.A., Teng R., Spurck T., Wetherbee R., The glucans extracted with warm water from diatoms are mainly derived from intracellular chrysolaminaran and not extracellular polysaccharides. Eur. J. Phycol., 2004, 39, 117-128.

22. Chou N.T., Cheng C.F., Wu H.C., Lai C.P., Lin L.T., Pan I.H., Ko C.H., Chlorella sorokiniana-Induced activation and maturation of human monocyte-derived dendritic cells through NF- $\mathrm{KB}$ and PI3K/MAPK pathways. J. Evidence-Based Complem. Altern. Med., 2012, 1-12, art. No. 735396. Doi:10.1155/2012/735396.

23. Chuecas L., Riley J.P., The component combined amino acids of some marine diatoms. J. Mar. Biol. Assoc. U. K., 1969, 49, 117-120.

24. Cimica V., Batusic D., Haralanova-Ilieva B., Chen Y., Hollemann T., Pieler T., Ramadori G., Serian analysis of gene expression (SAGE) in rat liver regeneration. Biochem. Biophys. Res. Commun., 2007, 360, 545-552.

25. Countinho P., Rema P., Otero A., Pereira O., Fábregas J., Use of biomass of the marine microalga Isochrysis galbana in the nutrition of goldfish (Carassius auratus) larvae as source of protein and vitamins. Aquacult. Res., 2006, 37, 793-798.

26. deMello-Samapayo C., Corvo M.L., Mendes R., Duarte D., Lucas J., Pinto R., Batista A.P., Raymundo A., Silva-Lima B., Bandarra N.M., Gouveia L., Insights on the safety of carotenogenic Chlorella vulgaris in rodents. Algal Res., 2013, 2, 409-415.

27. Deng R., Chow T.J., Hypolipidemic, antioxidant, and antiinflammatory Activities of microalgae Spirulina. Cardiovasc. Ther., 2010, 28, e33-e45.

28. Desbois A.P., Mearns-Spragg A., Smith V.J., A fatty acid from the Diatom Phaeodactylum tricornutum is antibacterial against diverse bacteria including multi-resistant Staphylococcus aureus (MRSA). Mar. Biotechnol., 2009, 11, 45-52.

29. Dillehay T.D., Ramírez C., Pino M., Collins M.B., Rossen J., Pino-Navarro J.D., Monte Verde: seaweed, food, medicine, and the peopling of South America. Science, 2008, 320(5877), 784-786.

30. Dineshkumar R., Dhanarajan G., Dash S.K., Sen R., An advanced hybrid medium optimization strategy for the enhanced productivity of lutein in Chlorella minustissima. Algal Res., 2015, 7, 24-32.

31. Domergue F., Spiekermann P., Lerchl J., Beckmann C., Kilian O., Kroth P.G., Boland W., Z hringer U., Heinz E., New insight into Phaeodactylum tricornutum fatty acid metabolism. Cloning and functional characterization of plastidial and microsomal $\Delta 12$-fatty acid desaturases. Plant Physiol., 2003, 131, 1648-1660.

32. Dörner J., Carbonell P., Pino S., Farias A., Variation on fatty acids in Isochrysis galbana (T-ISo) and Tetraselmis suecica, cultured under different nitrate availabilities. Fish Aquacult. J., 2014, 5, $3,1-3$.
33. Dragone G., Fernándes B.D., Abreu A.P., Vicente A.A., Teixeira J.A., Nutrient limitation as a strategy for increasing starch accumulation in microalgae. Appl. Energy, 2011, 88, 3331-3335.

34. Dunstan G.A., Brown M.R., Volkman J.K., Cryptophyceae and Rhodopyceae; chemotaxonomy, phylogeny, and application. Phytochemistry, 2005, 66(21), 2557-2570.

35. Duong V.T., Li Y., Nowak E., Schenck P.M., Microalgae isolation and selection for prospective biodiesel production. Energies, 2012, 5(6), 1835-1849.

36. Dvir I., Stark A.H., Chayoth R., Madar Z., Arad S.M., Hypocholesterolemic effects of nutraceuticals produced from red microalga Porphyridium in rats. Nutrients, 2009, 1, 156-167.

37. Fábregas J., Maseda A., Domínguez A., Ferreira M., Otero A., Changes in the cell composition of the marine microalga, Nannocchloropsis gaditana, during a light:dark cycle. Biotechnol. Lett., 2002, 24, 1699-1703.

38. Gantar M., Svircev Z., Microalgae and Cyanobacteria: food for thought. J. Phycol., 2008, 44, 260-268

39. García-Mendoza N.S., Pacheco-Ruiz I., Carotenoid composition of marine red algae. J. Phycol., 2006, 42, 1208-1216.

40. Gatenby C.M., Orcutt D.M., Kreeger D.A., Parker B.C., Jones V.A., Neves R.J., Biochemical composition of three algal species proposed as food for captive freshwater mussels. J. Appl. Phycol., 2003, 15, 1-11.

41. Gelin F., Boogers I., Noordellos A.A.M., Sinninghe-Damsté J.S., Hatcher P.G., De Leeuw J.W., Novel, resistant microalgal polyethers: An important sink of organic carbon in the marine environment?. Geochim. Cosmochim. Acta, 1996, 60(7), 1275-1280.

42. Geresh S., Arad S., Levy-Ontman O., Zhang W., Tekoah Y., Glaser R., Isolation and characterization of poly- and oligosaccharides from the red microalga Porphyridium sp. Carbohydr. Res., 2009, 344, 343-349.

43. Giles G.E., Mahoney C.R., Kanarek R., Omega-3 fatty acids influence mood in healthy and depressed individuals. Nutr. Rev., 2013, 71(11), 727-741.

44. Gilson P.R., McFadden G.I., Molecular, morphological and phylogenetic characterization of six chlorarchniophyte strains. Phycol. Res., 1999, 47, 7-19

45. Goiris K., Van-Colen W., Wilches I., León-Tamariz F., De Cooman L., Muylaert K., Impact of nutrient stress on antioxidant production in three species of microalgae. Algal Res., 2015, 7, 51-57.

46. Gómez-Casati D.F., Cortassa S., Aon M.A., Iglesias A.A., U1trasensitive behavior in the synthesis of storage polysaccharides in cyanobacteria. Planta, 2003, 215, 969-975.

47. González-López C.V., Cerón-García M.C., Fernandez F.G.A., Segovia-Bustos C., Chisti Y., Fernández-Sevilla J.M., Protein measurements of microalga and cyanobacterial biomass. Bioresour. Technol., 2010, 101(9), 7585-7591.

48. Guevara M., Bastardo L., Cortez R., Arredondo-Vega B., Romero, L., Gómez, P., Rhodomonas salina (Cryptophyta) pastes as feed for Brachionus plicatilis (Rotifera). Rev. Biol. Trop., 2011, 59(4), 1503-1515.

49. Guschina I.A., Harwood J.L., Lipids and lipid metabolism in eukaryotic algae. Prog. Lipid Res., 2006, 45, 160-186.

50. Harun R., Singh M., Forde G.M., Danquah M.K., Bioprocess engineering of microalgae to produce a variety of consumer. Renewable Sustainable Energy Rev., 2010, 14, 1037-1047 
51. Hempel F., Maier U.G., An engineered diatom acting like a plasma cell secreting human IgG antibodies with high efficiency. Microb. Cell Fact., 2012, 11, 126-132.

52. Hempel N., Petrick I., Behrendt F., Biomass productivity and productivity of fatty acids and amino acids of microalgae strains as key characteristics of suitability for biodiesel production. J. Appl. Phycol., 2012, 24, 1407-1418.

53. Herrero M., Simó C., García-Cañas V., Ibáñez E., Cifuentes A., Foodomics: MS-Based strategies in modern food science and nutrition. Mass Spectrom. Rev., 2012, 31, 49-69

54. Hirokawa Y., Fijiwara S., Suzuki M., Akiyama T., Sakamoto M., Kobayashi S., Tsuzuki M., Structural and physiological studies on the storage $\beta$-polyglucan of haptophyte Pleurochrysis haptonemofera. Planta, 2008, 227, 589-599.

55. Hosikian A., Lim S., Halim R., Danquah M.K., Chlorophyll extraction from microalgae. A review on the process engineering aspects. Int. J. Chem. Eng., 2010, 2010, 1-11.

56. Hu Q., Sommerfeld M., Jarvis E., Ghirardi M., Posewitz M., Seibert M., Darzins A., Microalgal triacylglycerols as feedstocks for biofuel production: perspectives and advances. Plant J., 2008, 54, 621-639.

57. Hu X., Yang X., Li L., Wu Y., Lin W., Huang H., Yang S., Antioxidant properties of microalgae protein hydrolysates prepared by neutral protease digestion. Appl. Mech. Mater., 2015, 707, 149-153.

58. Huangfu J., Liu J., Peng C., Suen Y., Wang M. Jiang Y., Chen Z.Y., Chen F., DHA-rich marine microalga Shizocytrium mangrovei possess anti-ageing effects on Drosophila melanogaster. J. Funct. Foods, 2013, 5, 888-896

59. Hulanicka D., Erwin J., Bloch K., Lipid metabolism of Euglena gracilis. J. Biol. Chem., 1964, 238(9), 2778-2787.

60. Kadkhodeaei S., Abbasiliasi S., Shun T.J., Masoumi H.R.F., Mohamed M.S., Movahedi A., Rahim R., Ariff A.B., Enhancement of protein production by microalgae Dunaliella salina under mixotrophic condition using response surface methodology. RSC Adv., 2015, 5, 38141-38151. DOI: 10.1039/C5RA04546K.

61. Kato H., Saito K., Kimura T.A., A perspective on DNA microarray technology in food and nutritional science. Curr. Opin. Clin. Nutr. Metab. Care, 2005, 8, 516-522.

62. Kerem M., Salman B., Pasaoglu H., Bedirli A., Alper M., Katircioglu H., Atici T., Perçin E.F., Ofluoglu E., Effects of microalgae Chlorella species crude extracts on intestinal adaptation in experimental short bowel syndrome. World J. Gastroenterol., 2008, 14(28), 4512-4517.

63. Khan Z., Bhadouria P., Bisen P.S., Nutritional and therapeutic potential of Spirulina. Curr. Pharm. Biotechnol., 2005, 6, 373-379.

64. Khozin-Goldberg I., Didi-Cohen S., Shayakhmetova I., Cohen Z., Biosynthesis of eicosapentaenoic acid (EPA) in the freshwater Eustigmatophyte Monodus subterraneus (Eustigmatophyceae). J. Phycol., 2002, 38, 745-756.

65. Kim S.K., Wijesekara I., Development and biological activities of marine-derived bioactive peptides: A review. J. Funct. Foods, 2010, 2, 1-9.

66. Koller M., Muhr A., Braunegg G., Microalgae as versatile cellular factories for valued products. Algal Res., 2014, 6, 52-63.

67. Kraan S., Algal Polysaccharides, Novel Applications and Outlook. 2012, In: Biochemistry, Genetics and Molecular Biology. Carbohydrates-Comprehensive Studies on Glycobiology and Glycotechnology (ed. Chuan-Fa Chang). InTech, CCBY., Rijeka, Croatia, pp. 489-532, ISBN 978-953-51-0864-1.
68. Kulshreshtha A., Zacharia J.A., Jarouliya U., Bhadauriya P., Prasad G.B.K.S., Bisen P.S., Spirulina in health care management. Curr. Pharm. Biotechnol., 2008, 9, 400-405.

69. Lang I.K., Hodac L., Friedl T., Feussner I., Fatty acid profiles and their distribution patterns in microalgae: a comprehensive analysis of more than 2000 strains from the SAG culture collection. BMC Plant Biol., 2011, 11, 124-140.

70. Lattimer J.M., Haub M.D., Effects of dietary fiber and is components on metabolic health. Nutrients, 2010, 2, 1266-1289.

71. Leblond J.D., Timofte H.I., Roche S.A., Porter N.M., Monoand diagalctosyl diacylglicerol composition of galucocystophytes (Glaucophyta): A modern interpretation using positive-ion electrospray ionization/mass spectrometry/mass spectrometry. Phycol. Res., 2010, 58(3), 222-229.

72. Lee J.Y., Kim Y.J., Kim H.J., Kim Y.S., Park W., Immunostimulatory effect of laminarin on RW264.7 mouse macrophages. Molecules, 2012, 17, 5404-5411.

73. Lichtlé C., Effects of nitrogen deficiency and light of high intensity on Cryptomonas rufescens (Cryptophyceae). Protoplasma, 1979, 101, 283-299

74. Liu C.Y., Zhao L., Han S., Li J.F., Li D.G., Identification and functional analysis of microRNAs in mice following focal cerebral ischemia injury. Int. J. Mol. Sci., 2015, 16(10), 24302-24318. doi:10.3390/ijms161024302

75. Loke M.F., Lui S.Y., Ng B.L., Gong M., Ho B., Antiadhesive property of microalgal polysaccharide extract on the binding of Helicobacter pylori to gastric mucin. FEMS Immunol. Med. Microbiol., 2007, 50, 231-238.

76. Lordan S., Ross R.P., Stanton C., Marine bioactives as functional food ingredients: Potential to reduce the incidence of chronic disease. Mar. Drugs, 2011, 9, 1056-1100.

77. Lüning K., Pang S.J., Mass cultivation of seaweeds: current aspects and approaches. J. Appl. Phycol., 2003, 15, 115-119.

78. Ma Y., Wang Z., Yu, Ch., Yin Y., Zhou G., Evaluation of the potential of 9 Nannochloropsis strains for biodiesel production. Bioresour. Technol., 2014, 167, 503-509.

79. Mairet F., Moisan M., Bernard O., Estimation of neutral lipid and carbohydrate quotas in microalgae using adaptive interval observers. Bioprocess Biosyst. Eng., 2014, 37, 51-61.

80. Markou G., Angelidaki I., Georgakakis D., Microalgal carbohydrates: an overview of the factors influencing carbohydrates production, and of main bioconversion technologies for production of biofuels. Appl. Microbiol. Biotechnol., 2012, 96, 631-645.

81. Markou G., Nerantzis E., Microalgae for high-value compounds and biofuels productions: A review with focus on cultivation under stress conditions. Biotechnol. Adv., 2013, 31(8), 1532-1542.

82. Maslova I.P., Mouradyan E.A., Lapina S.S., Klyachako-Gurvich G.L., Los D.A., Lipid fatty acid composition and thermophilicity of Cyanobacteria. Russ. J. Plant Physiol., 2004, 51(3), 353-360.

83. McFadden G.I., Gilson P.R., Sims I.M., Preliminary characterization of carbohydrate stores from Chlorarachniophytes (Division: Chlorarachniophyta). Phycol. Res., 1997, 43(3), 145-151.

84. McHugh D.J., A guide to the seaweed industry, FAO Fisheries Technical Papers 441. Food and Agriculture Organization of the United Nations. 2003, ISSN 0429-9345.

85. Miller M.R., Quek S.Y., Staehler K., Nalder T., Packer, M.A., Changes in oil content, lipid class and fatty acid composition of the microalga Chaetoceros calcitrans over different phases of batch culture. Aquacult. Res., 2014, 45, 1634-1647. 
86. Morris H.J., Almarales A., Carrillo O., Bermúdez R.C., Utilisation of Chlorella vulgaris cell biomass for the production of enzymatic protein hydrolysates. Bioresour. Technol., 2008, 99(16), 7723-7729.

87. Morris H.J., Carrillo O.V., Alonso M.E., Bermúdez R.C., Almarales A., Llauradó G., Lebeque Y., Fontaine R., Oral administration of an enzymatic protein hydrolysate from the Green Microalga Chlorella vulgare enhances the nutritional recovery of malnourished mice. J. Medic. Food, 2011, 14(12), 1583-1589.

88. Mulders K.J.M., Weesepoel Y., Lamers P.P., Vincken J.P., Martens D.E. Wijffels R.H., Growth and pigment accumulation in nutrient-depleted Isochrysis galbana T-ISO. J. Appl Phycol., 2013, 25, 1421-1430.

89. Müller P., Li X.P., Niyogi K.K., Non-phytochemical quenching. A response to excess light energy. Plant Physiol., 2001, 125, 1558-1566.

90. Nakamura Y., Takahashi J.I., Sakurai A., Inaba Y., Suzuki E., Nihei S., Fujiwara S., Tsuzuki M., Miyashi H., Ikemoto H., Kawashi M., Sekiguchi H., Kurano N., Some Cyanobacteria synthesize semi-amylopectin type $\alpha$-polyglucans instead of glycogen. Plant Cell Physiol., 2005, 46(3), 539-545.

91. Neyrinck A.M., Mouson A., Delzenne N.M., Dietary supplementation with laminarin, a fermentable marine $\beta$ (1-3) glucan, protects against hepatotoxicity induced by LPS in rat by modulation immune response in the hepatic tissue. Int. Immunopharmacol., 2007, 7, 1497-1506.

92. Nuño K., Villarruel-López A., Puebla-Pérez A.M., Romero-Velarde E., Puebla-Mora A.G., Ascencio F., Effects of the marine microalgae Isochrysis galbana and Nannochloropsis oculata in diabetic rats. J. Funct. Foods, 2013, 5, 106-115.

93. Nurachman Z., Hartini H., Rahmaniyah W.R., Kurnia D., Hidayat R., Prijamboedi B., Suendo V., Ratnaningsih E., Panggabean Z.M.G., Nurbaiti S., Tropical marine Chlorella sp. PP1 as a source of photosynthetic pigments for dye-sensitized solar cells. Algal Res., 2015, 10, 25-32.

94. Obata M., Taguchi S., The xanthophy II-cycling pigment dynamics of Isochrysis galbana (Prymnesiophyceae) during lightdark transition. Plankton Benthos Res., 2012, 7(3), 101-110.

95. Ohlrogge J., Browse J., Lipid biosynthesis. Plant Cell, 1995, 7, 957-970.

96. Olofsson M., Lamela T., Nilsson E., Bergé J.P., del Pino V., Uronen P., Legrand C., Seasonal variation of lipids and fatty acids of the microalgae Nannochloropsis oculata grow in outdoor large-scale photobioreactors. Energies, 2012, 5, 1577-1592.

97. Oren A., A hundred years of Dunaliella research: 1905-2005. Saline Syst., 2005, 1(2), 1-14. doi:10.1186/1746-1448-1-2.

98. Paulsen B.S., Vieira A.A.H., Klaveness D., Structure of extracellular polysaccharides produced by soil Cryptomonas sp. (Cryptophyceae). J. Phycol., 1992, 28(1), 61-63.

99. Peake J.M., Gobe G.C., Fassett R.G., Coombes J.S., The effects of dietary fish oil on inflammation, fibrosis and oxidative stress associated with obstructive renal injury in rats. Mol. Nutr. Food Res., 2011, 55, 400-410

100. Peng J., Yuan J.P., Wu C.F., Wang J.H., Fucoxanthin, a marine carotenoid present in seaweeds and diatoms: metabolism and bioactivities relevant to human health. Mar. Drugs, 2011, 9, 1806-1828.

101. Petkov G., García G., Which are fatty acids of the green alga Chlorella?. Biochem. Syst. Ecol., 2007, 35, 281-285.
102. Pulz O., Gross W., Valuable products from biotechnology of microalgae. Appl. Microbiol. Biotechnol., 2004, 65, 635-648

103. Raja R., Hemaiswarya S., Kumar N.A., Sridhar S., Rengasamy R.A., A perspective on the biotechnological potential of microalgae. Crit. Rev. Microbiol., 2008, 34, 77-88.

104. Ramachandra T.V., Mahapatra D.M., Karthick B., Gordon R., Milking diatoms for sustainable energy: biochemical engineering versus gasoline-secreting diatom solar panels. Ind. Eng. Chem. Res., 2009, 48, 8769-8788.

105. Raposo M.F.D.J., Costa de Morais R.M.S., Bernardo de Morais A.M.M., Bioactivity and applications of sulphated polysaccharides from marine microalga. Mar. Drugs, 2013, 11, 233-252.

106. Rebolloso-Fuentes M.M., Acien-Fernández G.G., Sánchez-Pérez J.A., Guil-Guerrero J.L., Biomass nutrient profiles of the microalga Porphyridium cruentum. Food Chem., 2000, 70(13), 345-353.

107. Roche S.A., Leblond J., Betaine lipids in chlorarachniophytas. Phycol. Res., 2010, 58, 298-305.

108. Rodolfi L., Zittelli G.C., Bassi N., Padovani G., Biondi N., Bonini G., Tredici M.R., Microalgae for oil: strain selection, induction of lipid synthesis and outdoor mass cultivation in a low-cost photobioreactor. Biotechnol. Bioeng., 2009, 102(1), 100-112.

109. Ryckebosch E., Bruneel C., Muylaert K., Foubert I., Microalgae as an alternative source of omega- 3 long chain polyunsaturated fatty acids. Lipid Technol., 2012, 24(6), 128-130.

110. Safi C., Ursu A.V., Laroche C., Zebia B., Merah O., Pontalier P.Y., Vaca-García C., Aqueous extraction of proteins from microalgae: Effect of different cell disruption methods. Algal Res., 2014, 3, 61-65.

111. Sahu A., Pancha I., Jain D., Paliwal C., Ghosh T., Patidar S., Bhattacharya S., Mishra S., Fatty acids as biomarkers of microalgae. Phytochemistry, 2013, 89, 53-58.

112. Samarakoon, K.W., Ko J.Y., Lee J.H., Kwon O.N., Kim S.W., Jeon Y.J., Apoptotic anticancer activity of a novel fatty alcohol ester isolated from cultured marine diatom, Phaeodactylum tricornutum. J. Funct. Foods, 2014, 6, 231-240.

113. Schwenzfeier A., Wierenga P.A., Gruppen H., Isolation and characterization of soluble protein from the green microalga Tetraselmis sp. Bioresour. Technol., 2011, 102, 9121-9127.

114. Senni K., Gueniche F., Foucault-Bertaud A., Ignondjo-Tchen S. Fioretti F., Colliec-Jouault S., Durand P., Guezennec J., Godeau G., Letoruneur D., Fucoidan a sulfated polysaccharide from brown algae is a potent modulator of connective tissue proteolysis. Arch. Biochem. Biophys., 2006, 445(1), 56-64.

115. Servaites J.C., Faeth J.L., Sidhu S.S., A dye binding method for measurement of total protein. Anal. Biochem., 2012, 421(1), 75-80.

116. Sharkey F.H., Banat I.M., Marchant R., Detection and quantification of gene expression in environmental bacteriology. Appl. Environ. Microbiol., 2004, 70(7), 3795-3806.

117. Shimonaga T., Konishi M., Oyama Y., Fujiwara S., Satoh A., Fujita N., Colleoni C., Buléon A., Putaux J.L., Ball S.G., Yokoyam A., Hara Y., Nakamura Y., Tsuzuki M., Variation in storage $\alpha$-glucans of the Porphyridiales (Rhodophyta). Plant Cell Physiol., 2008, 49(1), 103-116 doi:10.1093/pcp/pcm172, available online at [www.pcp.oxfordjournals.org].

118. Singh S., Kate B. N., Banerjee U.C., Bioactive compounds from cyanobacteria and microalgae: an overview. Crit. Rev. Biotechnol., 2005, 25(3), 73-95. 
119. Song P., Li L., Liu J., Proteomic analysis in nitrogen-deprived Isochrysis galbana during lipid accumulation. PLoS One, 2013, 8(12), e82188. Doi: 10.1371/journal.pone.0082188.

120. Stier H., Ebbeskotte V., Gruenwald J., Immunomodulatory effects of dietary yeast beta-1,3/1,6-D-glucan. Nutr. J., 2014, 13, $38-47$.

121. Su C.H., Fu C.C., Chang Y.C., Nair G.R., Ye J.L., Chu I.M., Wu W.T., Simultaneous estimation of chlorophyll $a$ and lipid contents in microalgae bye three-color analysis. Biotechnol. Bioeng., 2008, 99(4), 1034-1039. DOI 10.1002/bit.21623.

122. Tai CC., Ding S.T., N-3 polyunsaturated fatty acids regulate lipid metabolism through several inflammation mediators: mechanisms and implications for obesity prevention. J. Nutr. Biochem., 2010, 21, 357-363

123. Takaichi S., Carotenoids in algae: distribution, biosynthesis and functions. Mar. Drugs, 2011, 9, 1101-1118.

124. Takeyama H., Kanamaru A., Yoshino Y., Kakuta H., Kawamura Y., Matsunaga T., Production of antioxidant vitamins, $\beta$-carotene, vitamin $\mathrm{C}$, and vitamin $\mathrm{E}$, by two-step culture of Euglena gracilis Z. Biotechnol. Bioeng., 1997, 53(2), 185-190.
125. Templeton D.W., Laurens L.M.L., Nitrogen-to-protein conversion factors revisited for application of microalga biomass conversion to food, feed and fuel. Algal Res., 2015, 11, 359-367.

126. Tomaselli L., Biological Principles of Mass Cultivation. 2004, in: Handbook of Microalgal Culture: Biotechnology and Applied Phycology (ed. A. Richmond) Edit. Blackwell Publishing, Ltd. pp. 3-19, ISBN 0-632-0553-2.

127. Vinolo M.A.R., Rodrigues H.G., Nachbar R.T., Curi R., Regulation of Inflammation by short chain fatty acids. Nutrients, 2011, 3, 858-876.

128. Wikfors G.H., Ohno M., Impact of algal research in aquaculture. J. Phycol., 2001, 37, 968-974.

129. Wismar R., Brix S., Lærke H.N., Frøkiær H., Comparative analysis of a large panel of on-starch polysaccharides reveals structures with selective regulatory properties in dendritic cells. Mol. Nutr. Food Res., 2011, 55, 443-454.

130. Wutsman B.A., Gretz M.R., Hoagland K., Extracelluar matrix assembly in diatoms (Bacillariophyceae). Plant Physiol., 1997, 113, 1059-1069.

Submitted: 22 February 2017. Revised: 11 April 2017. Accepted: 27 April 2017. Published on-line: 13 September 2017. 
